\title{
Prostate Stem Cell Antigen
}

National Cancer Institute

\section{Source}

National Cancer Institute. Prostate Stem Cell Antigen. NCI Thesaurus. Code C50887.

Prostate stem cell antigen (123 aa, $\sim 13 \mathrm{kDa}$ ) is encoded by the human PSCA gene. This protein may play a role in the regulation of cell proliferation. 